\title{
38. 外国からのゴミ日本治岸に大量漂着
}

COASTAL POLLUTION BY FOREIGN DRIFTED GARBAGES.

\author{
山口晴幸*・横山芳春** \\ Hareyuki YAMAGUCHI, Yoshiharu YOKOYAMA
}

\begin{abstract}
In this report, the present authors discussed on the coastal pollution by foreign drifted garbages. The field investigations were carried out at the points of 224 in Japanese seashore-lines. The type and classification of foreign drifted garbages were investigated. It was points out from the results of field investigations that the coastal pollution by foreign drifted garbages was very important environmental problem in Japan.
\end{abstract}

KEYWORD; Coastal Pollution, Foreign Drifted Garbage, Coastal Environment

\section{1.はじめに}

我が国はアジア大陸の東端に位置し、東シナ海、日本海、オホーツク海、太平洋に囲まれ、5000 余りの 島々からなる弧状列島である。また東シ十海、日本海、オホーツク海を介して台湾、中華人民共和国 (中国)、 大韓民国（韓国）、ロシア連邦の極東と近接した地理環境にあり、我が国の海岸線は約 $34400 \mathrm{~km}$ 及んでい る。我が国最西端の島、与那国島（沖縄県）は台湾まで約 $125 \mathrm{~km}$ 、対馬（長崎県）は韓国まで約 $50 \mathrm{~km} の$ 位 置にある。台湾の東端を通り、東シナ海から流れ込む海流は奄美群島（鹿児島県）の西側で二つに分かれ、 対馬海流と黒潮（日本海流）となって、それぞれ日本海と太平洋の日本近海を北上している。

筆者は 1992 年 7 月より、日本列島の海岸線を回り、主に砂浜・海岸の污染状況や改変・破壊状況に関 する環境調査活動を継続している ${ }^{11,2)}$ 。その際特に、東北から北陸、山陰地方の日本海側の沿岸域や離島及 び奄美群島、沖縄諸島、先島群島などの東シ十海上の島々の砂浜・海岸では、外国からのものと思われる大 量の漂着物（ゴミ）が打ち上げられている状況に遭遇する機会がたびたびあった。これらの海岸線には小さ な漁村が多く、海や沿岸域を生活の糧としている住民の方々が多い。彼らからは、海岸域は我々にとって生 命の源であり、生活ゴミさえ海や海岸に投棄することは有り得ないという話を、現地で何度も伺ったことが ある。以前より海流に乗って海洋を漂流するプラスチック類のゴミをエサと誤って食べ、魚、海亀、海鳥な どの生物が死亡する例は、世界的に多数報告されてきている。海洋を漂流するゴミは、海洋污染の主要な因 子ともなっている。しかし我が国では、海洋を漂流した外国からのゴミが、広域な海岸線に亘って漂着し、 美しい自然景観を残している海岸線は、まさにゴミの山に化そうとしている問題が発生している。そこで、 海洋越境してくる外国からの漂着ゴミによる海岸污染の実態を提示し、我が国における漂着ゴミ污染問題に 早急に取り組むべき重要性に警鐘を鳴らすと共に、漂着ゴミによる海岸污染問題に関する対策や課題等につ いて論じる。

\section{2. 調査範囲と調査方法}

1997 年 2 月〜1998 年 1 月の期間で 224 地点の海岸域での調査を実施した。北海道小清水町のオホーツ

* ; 防衛大学校土木工学教室 Dept. of Civil Eng., National Defense Academy ** ; 茨城大学理学部地球生命環境科学科 Dept. of Earth Environment, Ibaragi Univ. 
ク海沿岸の海岸、秋田県男鹿半島西海岸から島根県七類の海岸に至る日本海沿岸域、福岡県から長崎県の沿 岸に掛けての九州玄界灘沿岸域、飛島 (山形県)、佐渡ヶ島 (新潟県)、舳倉島 (石川県)、隠岐諸島（島根 県)、平戸島、生月島、壱岐、対馬（長崎県）の各離島での海岸及び東シナ海上の奄美大島、加計呂麻島、 喜界島、徳之島 (鹿児島県)、沖縄本島、石垣島、竹富島、黒島、波照間島（沖縄県）の島々での海岸であ る。また、太平洋側では、相模湾・東京湾沿岸（神奈川県・千葉県）などの主な海岸である。

現地調査では、海岸域での目視観察によって外国からの漂着ゴミの個数と調査した海岸距離（調査範囲） を記録した。外国からの漂着ゴミの確認・識別は、ゴミに付着しているラベルや直接標記している文字から 行った（写真-1）。そのために外国からの漂着ゴミと思われるが、ラベルがはげたり、表示が消えていて、 明確に判断できないものは除外している。ハングル語系、中華語系、ロシア語系以外は、英字とアラビア文 字系である。なお中華語系での台湾系と中国系（旧香港含む）の判別は、製造地名やバーコードを利用して 行った。

\section{3. 外国からの漂着ゴミによる海岸污染の実態}

外国からの漂着ゴミが確認された海岸地点数は、調査海岸地点総数（224 箇所）の 60\%（135 箇所）を 占め、北海道オホーツク海沿岸から先島群島に亘る、広域な海岸域に及んでいる。外国からの漂着ゴミが確 認された海岸の状況を図-1に示している。特に、外国からの漂着ゴミの多い海岸を図-1 に@印で明示し表-1

・ : 外国からの漂着ゴミ確認海岸域

調查海岸域の地域別区分

（）の表示：(調查海岸地点数*確認コミ個数（個）*調查海岸総距踓 $(\mathrm{km})$ )

(ㅇ：特に外国ゴミの多い海岸域

北海道オホーツク海沿岸

九州玄界淮沿岸、热岐、刘䭴の抗大图

対馬 $(1 * 41 * 3)$

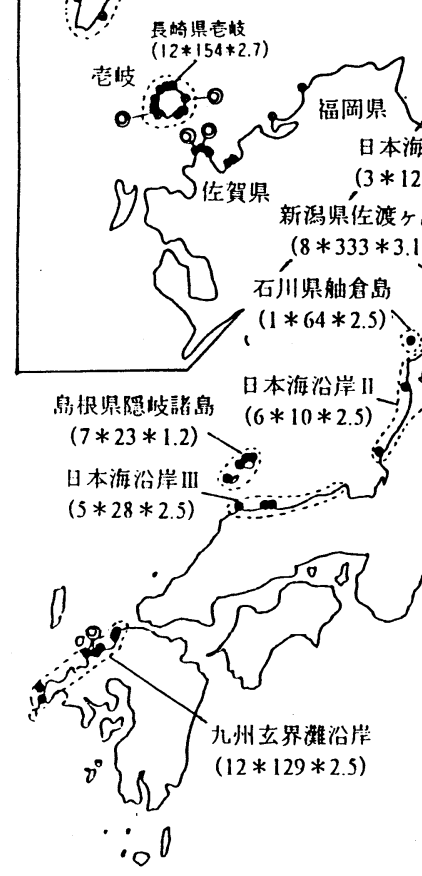

(a) 北海道〜九州地方 の海岸域
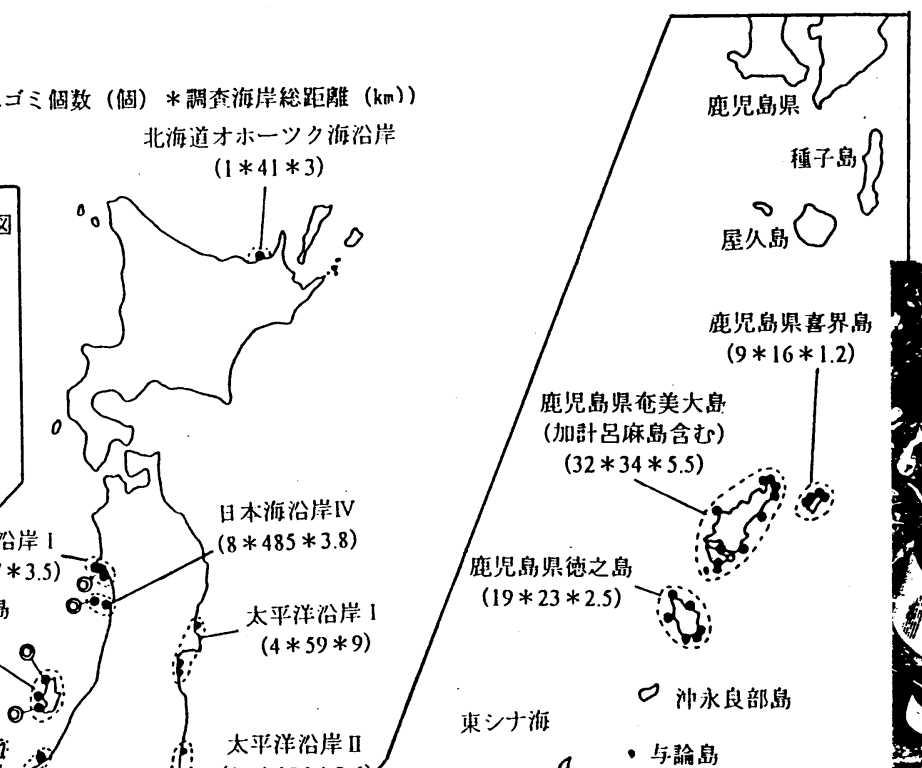
にまとめている。

海洋越境して来る外国からの漂着ゴミ類は、プラスチック類、金属製缶類、ガラス製ビン類、ポリエチ レン・ポリプロピレン製シート・袋類、漁具類に大別できる。圧倒的に多いのはプラスチック類の漂着ゴミ

表-1 外国からの漂着ゴミの特に多い海岸域

\begin{tabular}{|c|c|c|c|c|c|c|}
\hline 県 名 & 地 域 名 等 & $\begin{array}{llll} & \text { 岸 } & \text { 等 }\end{array}$ & 調 查日 & $\begin{array}{l}\text { 確認個数 } \\
\text { (個) }\end{array}$ & $\begin{array}{c}\text { 調查距離 } \\
(\mathrm{km})\end{array}$ & $\begin{array}{c}1 \mathrm{~km} \text { 当りの個数 } \\
(\text { 個 } / \mathrm{km})\end{array}$ \\
\hline \multirow[t]{3}{*}{ 秋田県 } & 日本海沿岸域 & 戸賀湾一帯の海岸 & H9.9.13 & 44 & 1.5 & 30 \\
\hline & (男鹿半島西海岸) & 鶇ノ崎〜増田の海岸 & H9.9.14 & 47 & 1.5 & 32 \\
\hline & 日本海沿岸域 & 出戸浜一帯 & H9.9.14 & 36 & 0.5 & 72 \\
\hline \multirow[t]{5}{*}{ 山形県 } & 飛島 & 八幡崎の西方の浜 & H9.9.22 & 57 & 0.5 & 114 \\
\hline & （日本海上） & 田下〜青石一帯の浜 & H9.9.22 & 61 & 0.6 & 102 \\
\hline & & ミヤダ浜 & H9.9.22 & 35 & 0.4 & 88 \\
\hline & & 荒崎西方の浜 & H9.9.21 & 129 & 0.5 & 258 \\
\hline & & ゴドロ浜 & H9.9.22 & 102 & 0.6 & 170 \\
\hline \multirow[t]{5}{*}{ 新潟県 } & 佐渡ヶ島 & 岩谷口の海岸 & H9.10.7 & 115 & 0.6 & 192 \\
\hline & (日本海上) & 真野新町〜豊田一帯の浜 & H9.10.8 & 37 & 0.5 & 74 \\
\hline & & 椿尾海水浴場 & H9.10.8 & 45 & 0.2 & 225 \\
\hline & & 素浜魚港付近の海岸 & H9.10.8 & 27 & 0.1 & 270 \\
\hline & & 素浜海岸 & H9.10.8 & 80 & 1.2 & 67 \\
\hline 石川県 & 舳倉島（日本海上） & 北部海岸一帯 & H9.5.2 & 64 & 2.5 & 26 \\
\hline \multirow[t]{2}{*}{ 佐賀県 } & 玄界灘沿岸域 & 波戸岬一帯の岩場 & H9.7.21 & 52 & 1 & 52 \\
\hline & & 大友海岸 & H9.7.21 & 29 & 0.3 & 97 \\
\hline \multirow[t]{3}{*}{ 長崎県 } & 壱岐（日本海上） & 里浜海水浴場 & H9.7.10 & 25 & 0.1 & 250 \\
\hline & & 清石浜海水浴場 & H9.7.11 & 63 & 0.4 & 158 \\
\hline & 対馬 (日本海上) & 小茂田浜海水浴場 & H9.7.14 & 43 & 0.2 & 215 \\
\hline \multirow[t]{8}{*}{ 沖縄県 } & 石垣島 & 登野城・真栄里一帯の海岸 & H9.8.11 & 80 & 2 & 40 \\
\hline & （東シナ海上） & 白保海岸一帯 & H9.8.12 & 114 & 0.5 & 228 \\
\hline & & 明石浜一帯 & H9.8.13 & 77 & 1.5 & 52 \\
\hline & & 平野・浦崎一帯の海岸 & H9.8.13 & 116 & 1 & 116 \\
\hline & 竹富島（東シナ海上） & 南東側一帯の海岸 & \begin{tabular}{|l|} 
H9.8.14 \\
\end{tabular} & 54 & 2.3 & 24 \\
\hline & 黒島（東シナ海上） & 北西南側一帯の海岸 & H9.8.14 & 120 & 4.2 & 29 \\
\hline & 西表島（東シナ海上） & 南風見田の浜一帯 & $\begin{array}{ll}\mathrm{H} 9.8 .12 \\
\mathrm{H} 98.12\end{array}$ & 109 & 2.5 & 44 \\
\hline & 波照間島（東シナ海上） & 一部の海岸 & \begin{tabular}{|l|l|}
$H 9.8 .15$ \\
\end{tabular} & 71 & $\frac{1.5}{3}$ & 24 \\
\hline 茨城県 & 太平洋沿岸域（鹿島灘） & 土合〜舎利一帯の浜 & H9.12.31 & 79 & 2.5 & 32 \\
\hline 千葉県 & $\begin{array}{l}\text { 太平洋沿岸 } \\
\text { (南房総沿岸) }\end{array}$ & 平砂浦海岸 & H9.11.2 & 84 & 3.6 & 24 \\
\hline
\end{tabular}

類である。これはジュース・ミネラルウオーター・酒等飲料用のペットボトルの容器類と洗剤・化粧品・薬 品用等の容器類が主体である。特に外国からの漂着ゴミが確認できた地点では、かならずプラスチック類の ゴミが確認される。金属製缶類はオイル缶、ビール缶、ガスボンベ缶、スプレー缶類が主体で、これらもか なり多く漂着している。またポリエチレン・ポリプロチレン製の袋やシート及び発泡スチロール製の物質も 漂着している。袋類では、チューブ付点滴用の医療廃棄物が漂着している海岸もあった。漁具類の漂着ゴミ も多く、プラスチック類の大型の浮きや漁網などが大量に漂着している海岸も多い。さらにビールケースの ラッグ、ドラム缶、ガスボンベのような識別不明物体など、北常に人型のゴミが漂着している海岸もある。

外国からの漂着ゴミと識別できるものは、せいぜい 10〜30\%程度である。個人的な調査では、広域な海 岸線での漂着ゴミの詳細な定量的評価は難しいが、識別不能な漂着ゴミが圧倒的に多い。これがどの程度外 国からの漂着ゴミなのか否か判断する方法はない。漂着ゴミの量は季節的にもかなり異っている。秋から冬、 春時期に掛けては、台風や強風、高波など荒天候の頻度が多いため、何度も打ち上げられた漂着ゴミが浜を 一面に埋め尽くしている光景に遭遇する機会が多い。またこの時期には、海岸清掃もほとんど行われないの で、外国からの漂着ゴミが 50〜80\%に達している海岸もある。

図-1 に示した北海道小清水町のオホーツク海沿岸、秋田県男鹿半島から島根県七類に至る日本海沿岸、 九州玄界灘沿岸と近海の離島（飛島、佐渡ヶ島、舳倉島、隠岐諸島、壱岐、対馬）及び奄美群島、沖縄本島、 先島群島の島々での調査結果によれば、日本海側の離島や東シナ海上の島々及びオホーツク海沿岸、男鹿半 島西海岸周辺、玄界灘沿岸の海岸では、外国からの漂着ゴミが大量に目についた。特に、飛島（山形県）、 
佐渡ヶ島 (新潟県)、舳倉島 (石川県)、隱岐諸島 (島根県)、壱岐 (長崎県)、対馬 (長崎県)、喜界島 (鹿 児島県) 石垣島 (沖縄県)、西表島（沖縄県）の離島では、外国からの漂着ゴミで埋めつくされ、まさにゴ ミ箱と化した海岸がかなり存在している（写真-1）。飛島、壱岐、対馬の地域住民の方々の話によれば、秋 から冬場の強風や高波の時期には、外国からの漂着ゴミが 70〜80\%を占める海岸も多いと言う。小清水海 岸 (北海道小清水町)、男鹿半島西海岸 (秋田県象潟町)、出戸浜 (秋田県天王町)、象潟海岸 (秋田県象潟 町)、大友海岸（佐賀県呼子町）、恋の浦海岸（福岡県津屋崎町）などのオホーツク海、日本海、玄界灘に面 した海岸線にも外国からの漂着ゴミが非常に目立った。小清水海岸、琴ヶ浜 (石川県門前町)、琴引浜 (京 都府網野町)、井手ヶ浜（鳥取県青谷町）、青谷海水浴場（鳥取県青谷町）、恋の浦など、著名な「鳴き砂」 の海岸も多い。恋の浦海岸はかつてより「鳴き砂」の浜として学術的に貴重な砂浜であった。今回、踏査し た時は、漂着ゴミの多さに驚き、まさに「ゴミに泣く浜」という印象を強く受けた。また外国からの漂着ゴ ミは、東北から関東地方の太平洋側の調査海岸地点においても確認された。

外国からの漂着ゴミがどのような経緯で我が国の海岸域に漂着するかについての詳細は、現状では不明 であり、今後解明していく必要がある。しかし

(1) 広域の海岸域に亘って漂着していること。

(2) 大量に漂着している海岸も多いこと。

(3) 漂着ゴミも多岐の種類に亘っていること。

などの実態を考えると、船上等からのポイ捨て的な行為に因るものではないと判断できる。何らかの行為・ 原因によって、我が国の領海外の海上で浮遊・漂流していたゴミが、海流や沿岸流に乗って移動し、領海を 越えて我が国の海岸域に漂着してきたものと推察される。

\section{4. 外国からの漂着ゴミの産出・発生源と定量的評価}

外国からの漂着ゴミの分析は、あくまでも、漂着状態において、明瞭に識別できるものだけを対象とし ている。このような識別できる外国からの漂着ゴミは、漂着ゴミ総量のせいぜい 10～20\%程度で、多い海 岸でも50\%以内である。

日本列島での 224 箅所の調査地点を、北海道から先島群島に亘って、25 地域に区分して、分析・評価を 試みた（図-1）。表-2 には、それぞれ各調査地域での調査海岸地点数（A 欄）とその区域での外国からの漂 着ゴミが確認された海岸の有無を示す海岸地点数（Bと C 欄）を示している。確認された外国からの漂着 ジミの個数をハングル語系、中華語系、ロシア語系、その他（英字系等）の4タイプにメ分した。中華語系 はさらに台湾系と中国系（旧香港含む）に細分化している。その他（英字系等）には、英語系、アラビア語 系、マレーシア語系、インドネシア語系などが主体となっている。表-2 中の調査海岸の総距離数（kn) は、 地域区分した各海岸域で、外国からの漂着ゴミの有無に関わらず、各海岸での調査した海岸長距離を総和し たものである。

そこで表-2 に示す結果に基づき、調査地域別に、外国からの漂着ゴミの数個から漂着ゴミの産出・発生 源の区分割合、外国からの漂着ゴミが確認された海岸地点数の割合（表-2 中の A 欄に対寸る B 欄の数值の 比率)、「漂着ゴミ総量 (個)」を「調査海岸の総距離数 $(\mathrm{km}) 」 て ゙$ 除し、単位距離当たりの外国からら漂着ゴ ミの平均的個数（「調査距離当りのゴミ数（個数 $\mathrm{km}$ ）欄」）を算出した（表-3）。

外国からの漂着ゴミが確認された海岸地点数の割合状況を図-2 に、また単位距離当りの外国からの漂着 ゴミの平均的個数状況を図-3 に比較している。外国からの漂着ゴミが確認された海岸地点数の割合や漂着 ゴミ個数は、奄美大島、喜界島、徳之島の奄美群島と沖縄本島では、それぞれ 50\%以下と 10 個程度で、他 の調査地域に比較してかなり少ない值となっている。日本海沿岸 I と II 及び太平洋IV と相模湾・東京湾沿 岸地域を除いた他の地域では、確認された海岸地点数の割合も $70 \%$ 以上で $100 \%$ の場合が多く、ほとんどの 
海岸で、外国からの漂着ゴミが確認される。なお、舳倉島、竹富島、黒島、西表島、波照間島の離島では、 島周囲が踏査できる海岸線で連続しているので、数個の海岸をまとめて調査海岸地点数を 1〜2 としている。 また、日本海沿岸 II とIII゙は、確認された海岸地点数の割合も50\%と 60\%で、漂着ゴミ個数も 4 個と 12 個と比較的少ない值を示している。これは、ロシアタンカーによる重油流出災害によって、海岸域が調査時 にかなり清掃された痕跡があり、その影響によるものと考えられる。周辺の調査地点や地域の結果から判断 すると、本来もっと外国からのゴミの漂着度合は高いと推測される。隠岐諸島と喜界島では、平均的に漂着 表-2(a) 調査地域別による外国からの漂着ゴミの区分と量的状況（日本海・東シナ海側）

\begin{tabular}{|c|c|c|c|c|c|c|c|c|c|c|c|c|c|}
\hline \multirow{3}{*}{ 調查地域区分 } & \multirow{3}{*}{ 调查地点等 } & \multirow{3}{*}{ 調查日 } & \multirow{3}{*}{\begin{tabular}{l|l}
$\mathrm{A}$ \\
橍
\end{tabular}} & \multirow{3}{*}{$\begin{array}{c}\text { B } \\
\text { 桐 }\end{array}$} & \multirow{3}{*}{ 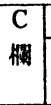 } & \multicolumn{6}{|c|}{ 確諗された外国からの漂着コミ数(個)と産出源区分 } & \multirow{3}{*}{$\begin{array}{l}\text { 漂着ゴミ } \\
\text { 総量 (個) }\end{array}$} & \multirow{3}{*}{ 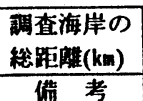 } \\
\hline & & & & & & \multirow{2}{*}{$\begin{array}{l}\text { ツリグ } \\
\text { 䛇系 }\end{array}$} & \multicolumn{3}{|c|}{ 中華語系 } & \multirow{2}{*}{\begin{tabular}{|l|} 
口シア \\
語系
\end{tabular}} & \multirow{2}{*}{$\begin{array}{l}\text { その他 } \\
\text { (英字系等) }\end{array}$} & & \\
\hline & & & & & & & 台唀系 & 中国系 & 合計 & & & & \\
\hline 北敏道林一"旅沿岸 & 小清水海岸一带 & H9.9.4 & 1 & 1 & - & 32 & - & - & - & 8 & 1 & 41 & 3 \\
\hline 日木海沿岸 I & $\begin{array}{l}\text { 秋田県男鹿半帛 } \\
\text { 周辺 }\end{array}$ & $\begin{array}{l}9.9 .13 \\
H 9.9 .14 \\
\end{array}$ & 3 & 3 & -1 & 108 & 8 & 7 & 15 & $\overline{-}$ & 4 & 127 & 3.5 \\
\hline $\begin{array}{l}\text { 日本旅沿岸IV } \\
\text { (发易等) }\end{array}$ & 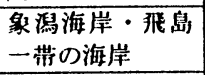 & \begin{tabular}{|l|}
$H 9.9 .21$ \\
H9.9.22 \\
\end{tabular} & 8 & 8 & - & 417 & 6 & 26 & 32 & 13 & 23 & 485 & 3.8 \\
\hline 新潟県佐渡ヶ白 & $\begin{array}{l}\text { 日本海侧の海岸 } \\
\text { 域 }\end{array}$ & $\begin{array}{l}\text { H9.10.7 } \\
\text { H9.10.8 }\end{array}$ & 8 & 8 & - & 287 & 8 & 21 & 29 & 1 & 16 & 333 & 3.1 \\
\hline \multirow[t]{2}{*}{ 日本海沿岸 II } & 新潟県名立町〜 & \begin{tabular}{|l|} 
H9.4.29 \\
\end{tabular} & \multirow[t]{2}{*}{6} & \multirow[t]{2}{*}{3} & \multirow[t]{2}{*}{3} & \multirow[t]{2}{*}{9} & \multirow[t]{2}{*}{-} & \multirow[t]{2}{*}{-} & \multirow[t]{2}{*}{-} & \multirow[t]{2}{*}{-} & \multirow[t]{2}{*}{1} & \multirow[t]{2}{*}{10} & 2.5 \\
\hline & $\begin{array}{l}\text { 褔井県三国町の } \\
\text { 海岸 }\end{array}$ & H9.5.2 & & & & & & & & & & & $\begin{array}{l}\text { 重油漂着に } \\
\text { より清掃後 } \\
\end{array}$ \\
\hline 石川界舳令泉 & 北部海岸一州 & H9.5.2 & 1 & 1 & - & 57 & - & 4 & 4 & - & 3 & 64 & 2.5 \\
\hline 葛根県隠岐諸岛 & $\begin{array}{l}\text { 岛後・岛前の一- } \\
\text { 部海岸 }\end{array}$ & $\begin{array}{l}\text { H9.4.26 } \\
\text { H9.4.27 }\end{array}$ & 7 & 5 & 2 & 22 & - & $T$ & 1 & - & - & 23 & 1.2 \\
\hline \multirow[t]{2}{*}{ 日本海沿岸 1 III } & \multirow{2}{*}{$\begin{array}{l}\text { 京都府網野町〜 } \\
\text { 息根照美保関町 } \\
\text { の海岸 }\end{array}$} & \multirow{2}{*}{$\begin{array}{c}\text { H9.4.25 } \\
\sim \\
\text { H9.4.29 }\end{array}$} & \multirow[t]{2}{*}{5} & \multirow[t]{2}{*}{3} & \multirow[t]{2}{*}{2} & 27 & - & 1 & 1 & - & - & 28 & 2.5 \\
\hline & & & & & & & & & & & & & $\begin{array}{l}\text { 重油漂着に } \\
\text { より清掃後 } \\
\end{array}$ \\
\hline 九州玄界灘沿岸 & 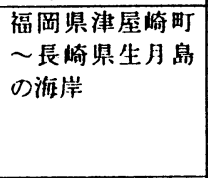 & $\begin{array}{l}9.2 .8 \\
\text { H9.2.9 } \\
\text { H9.7.10 } \\
\text { H9.7.11 } \\
\text { H9.7.21 } \\
\text { H9.7.22 } \\
\end{array}$ & 12 & 10 & 2 & 103 & 5 & 18 & 23 & - & 3 & 129 & 2.5 \\
\hline 言崎祡壱岐 & 泉一带の海岸 & $\begin{array}{l}\text { H9.7.10 } \\
\text { H9.7.11 } \\
\end{array}$ & 12 & 11 & 1 & 115 & 10 & 20 & 30 & - & 9 & 154 & 2.7 \\
\hline 長猗県対照 & 帛一部の海岸 & $\begin{array}{l}\text { H9.7.13 } \\
\text { H9.7.14 }\end{array}$ & 5 & 5 & - & 68 & 5 & - & 5 & - & - & 73 & 1.2 \\
\hline 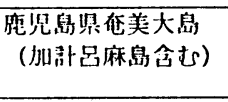 & 易一带の海岸 & $\begin{array}{l}\text { H9.4.1 } \\
\sim \\
\text { H9.4.10 } \\
\end{array}$ & 32 & 9 & 23 & 29 & 1 & 4 & 5 & - & - & 34 & 5.5 \\
\hline 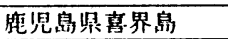 & 泉一带の海岸 & H9.4.9 & 9 & 4 & 5 & 10 & 2 & 3 & 5 & - & 1 & 16 & 1.2 \\
\hline 鹿個自県徳之息 & 岛一带の潕岸 & \begin{tabular}{|c|} 
H9.3.28 \\
$\sim \widetilde{\sim}$ \\
H9.3.31 \\
\end{tabular} & 19 & 6 & 13 & 20 & 2 & 1 & 3 & - & - & 23 & 2.5 \\
\hline 沖級県沖紞本泉 & 白一带の海岸 & $\begin{array}{c}\text { H9.8.18 } \\
\sim \\
\text { H9.8.23 } \\
\end{array}$ & 26 & 12 & 14 & 25 & 4 & 7 & 11 & - & 1 & 37 & 4.5 \\
\hline 洲稆界石垣泉 & 易一部の海岸 & $\begin{array}{c}\text { H9.8.11 } \\
\sim \\
\text { H9.8.13 } \\
\end{array}$ & 6 & 6 & - & 77 & 207 & 56 & 263 & - & 61 & 401 & 5.3 \\
\hline 洲級県竹管息 & 南東侧海岸 & H9.8.14 & 1 & 1 & - & 6 & 28 & 8 & 36 & - & 12 & 54 & 2.3 \\
\hline 沖級歨黑泉 & 北西南側海岸 & H9.8.14 & 1 & 1 & - & 14 & 71 & 12 & 83 & - & 23 & 120 & 4.2 \\
\hline 沖糺県西表泉 & 南東侧海岸 & H9.8.12 & 2 & 2 & - & 29 & 97 & 43 & 140 & - & 51 & 220 & 3.8 \\
\hline 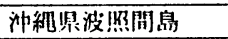 & 西側海岸 & H9.8.15 & 1 & 1 & - & 5 & 46 & 6 & 52 & - & 14 & 71 & 3 \\
\hline
\end{tabular}

表-2(b) 調査地域別による外国からの漂着ゴミの区分と量的状況（太平洋側）

\begin{tabular}{|c|c|c|c|c|c|c|c|c|c|c|c|c|c|}
\hline \multirow{3}{*}{ 調査地域区分 } & \multirow{3}{*}{ 調 査 地 点 等 } & \multirow{3}{*}{ 調 査 日 } & \multirow{3}{*}{$\begin{array}{c}\mathrm{A} \\
\text { 欄 }\end{array}$} & \multirow{3}{*}{$\begin{array}{c}\mathrm{B} \\
\text { 欄 }\end{array}$} & \multirow{3}{*}{$\begin{array}{c}\mathrm{C} \\
\text { 欄 }\end{array}$} & \multicolumn{6}{|c|}{ 確認された外国からの漂着ゴミ数（個）と産出源区分 } & \multirow{3}{*}{$\begin{array}{l}\text { 漂着 ゴミ } \\
\text { 総量（個） }\end{array}$} & \multirow{3}{*}{\begin{tabular}{|c}
$\begin{array}{l}\text { 調査海岸の } \\
\text { 総距灕 }(\mathrm{km})\end{array}$ \\
備考 \\
\end{tabular}} \\
\hline & & & & & & \multirow{2}{*}{$\begin{array}{l}\text { ハングル } \\
\text { 語系 }\end{array}$} & 中 & 華 語 & 采 & \multirow{2}{*}{$\begin{array}{l}\text { ロシア } \\
\text { 語系 }\end{array}$} & \multirow{2}{*}{$\begin{array}{l}\text { その他 } \\
\text { (英字系等) }\end{array}$} & & \\
\hline & & & & & & & 台湾系 & 中国系 & 合計 & & & & \\
\hline 太平洋沿岸 I & 宮城県沿岸 & $\begin{array}{c}\text { H9.12.30 } \\
\sim \\
\text { H10.1.4 }\end{array}$ & 4 & 3 & 1 & 47 & 2 & 2 & 4 & - & 8 & 59 & 9 \\
\hline 太平洋沿岸 II & $\begin{array}{l}\text { 福岛〜千葉県沿岸 } \\
\text { (主に鹿島灘沿岸) }\end{array}$ & $\begin{array}{c}\text { H9.10.17 } \\
\sim \\
\text { H9.12.31 }\end{array}$ & 10 & 7 & 3 & 79 & 15 & 8 & 23 & 1 & 3 & 106 & 3.6 \\
\hline 太平洋沿岸 III & $\begin{array}{l}\text { 南房総沿岸 } \\
\text { (平砂浦海岸) }\end{array}$ & H9.11.2 & 1 & 1 & - & 22 & 13 & 25 & 38 & - & 24 & 84 & 3.6. \\
\hline 太平洋沿岸IV & $\begin{array}{l}\text { 愛知県策島・伊良湖 } \\
\text { 沿岸 }\end{array}$ & H10.1.21 & 3 & 1 & 2 & - & - & 1 & 1 & - & 2 & 3 & 4.9 \\
\hline $\begin{array}{l}\text { 相模湾·東京湾 } \\
\text { 沿岸 }\end{array}$ & 神奈川・千葉県沿岸 & $\begin{array}{c}\text { H9.4.17 } \\
\sim \\
\text { H10.1.4 }\end{array}$ & 39 & 2 & 16 & 25 & 15 & 32 & 47 & - & 15 & 87 & 20 \\
\hline
\end{tabular}

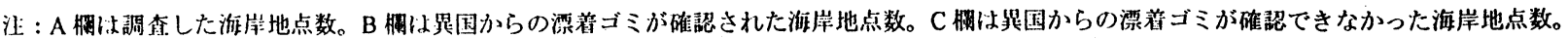


表-3(a) 調査地域別による外国からの漂着ゴミの区分比率状況（日本海・東シ十海側）

\begin{tabular}{|c|c|c|c|c|c|c|c|}
\hline 調查地域区分 & 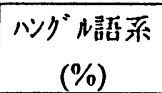 & \multicolumn{2}{|c|}{ 中菲話系 ( \% ) } & 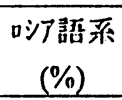 & $\begin{array}{l}\text { その他(英字 } \\
\text { 系等)(\%) }\end{array}$ & \begin{tabular}{|l}
$\begin{array}{l}\text { 漂着海岸 } \\
\text { 比率(\%) }\end{array}$ \\
\end{tabular} & 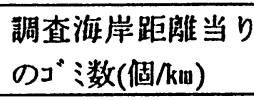 \\
\hline \multirow[t]{2}{*}{ 北敏道林・ッ海沿岸 } & \multirow[t]{2}{*}{78} & \multicolumn{2}{|c|}{ - } & \multirow[t]{2}{*}{20} & \multirow[t]{2}{*}{2} & \multirow[t]{2}{*}{100} & \multirow[t]{2}{*}{14} \\
\hline & & - & - & & & & \\
\hline \multirow[t]{2}{*}{ 日本海㳂岸 I } & \multirow[t]{2}{*}{85} & \multicolumn{2}{|c|}{12} & \multirow[t]{2}{*}{-} & \multirow[t]{2}{*}{3} & \multirow[t]{2}{*}{100} & \multirow[t]{2}{*}{36} \\
\hline & & 53 & 47 & & & & \\
\hline \multirow{2}{*}{$\begin{array}{l}\text { 日本海沿岸IV } \\
\text { (飛禺泉等) }\end{array}$} & \multirow[t]{2}{*}{86} & \multicolumn{2}{|c|}{6} & \multirow[t]{2}{*}{3} & 5 & 100 & 128 \\
\hline & & 19 & 81 & & & & \\
\hline 新潟些佳湾ヶ㿟 & 86 & & 7 & 0.3 & 5 & 100 & 108 \\
\hline & & 28 & 72 & & & & \\
\hline 日本海沿岸 II * & 90 & & 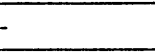 & - & 10 & 50 & 4 \\
\hline & & - & - & & & & \\
\hline 石川紫舳令泉 & 89 & . & ; & - & 5 & 100 & 26 \\
\hline & & - & 100 & & & & \\
\hline 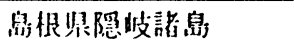 & 96 & 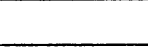 & & - & - & 71 & 20 \\
\hline & & - & 100 & & & & \\
\hline 日本海沿岸 III* & 96 & & & - & - & 60 & 12 \\
\hline & & - & 100 & & & & \\
\hline 九州立界灘沿岸 & 80 & & 8 & - & 2 & 83 & 52 \\
\hline & & 22 & 78 & & & & \\
\hline 层崎紫苍岥 & 75 & & 9 & - & 6 & 92 & 57 \\
\hline & & 33 & 67 & & & & \\
\hline 辰崎赑対熙 & 93 & & & - & - & 100 & 61. \\
\hline & & 100 & - & & & & \\
\hline 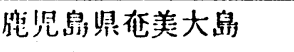 & 85 & & & - & - & 28 & 7 \\
\hline & & 20 & 80 & & & & \\
\hline 肬児鼠県喜界島 & 63 & & & - & 6 & 44 & 13 \\
\hline & & 40 & 60 & & & & \\
\hline 鹿児泉浆徳之島 & 87 & & & - & - & 32 & 10 \\
\hline & & 67 & 33 & & & & \\
\hline 洲和紫沖和本泉 & 67 & & & - & 3 & 46 & 8 \\
\hline & & 36 & 64 & & & & \\
\hline 洲秃県石垣㿣 & 19 & & & - & 15 & 100 & 76 \\
\hline & & 79 & 21 & & & & \\
\hline 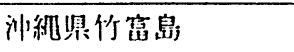 & 11 & & & - & 22 & 100 & 23 \\
\hline & & 78 & 22 & & & & \\
\hline 洲种祡黑鼠 & 12 & & & - & 19 & 100 & 29 \\
\hline & & 86 & 14 & & & & \\
\hline 洲級県西表帛 & 13 & & & - & 23 & 100 & 58 \\
\hline & & 69 & 31 & & & & \\
\hline 测秃紫波照間鼠 & 7 & & & - & 20 & 100 & 24 \\
\hline & & 88 & 12 & & & & \\
\hline
\end{tabular}

表-3(b) 調査地域別による外国からの漂着ゴミの区分比率状況（太平洋側）

\begin{tabular}{|c|c|c|c|c|c|c|c|}
\hline \multirow{2}{*}{ 調 査 地 域 区 分 } & \multirow{2}{*}{$\begin{array}{l}\text { ハングル語系 } \\
(\%)\end{array}$} & \multicolumn{2}{|c|}{ 中華語系 (\%) } & \multirow{2}{*}{$\begin{array}{c}\text { ロシア語系 } \\
(\%)\end{array}$} & \multirow{2}{*}{$\begin{array}{l}\text { その他(英 } \\
\text { 字系等)(\%) }\end{array}$} & \multirow{2}{*}{$\begin{array}{l}\text { 漂着海岸 } \\
\text { 比率(\%) }\end{array}$} & \multirow{2}{*}{$\begin{array}{l}\text { 調査海岸距離当り } \\
\text { のゴミ数 (個/ } / \mathrm{km})\end{array}$} \\
\hline & & 台湾系 (\%) & 中国系 (\%) & & & & \\
\hline \multirow{2}{*}{ 太平洋沿岸 I } & \multirow[t]{2}{*}{80} & & $\frac{7}{7}$ & \multirow[t]{2}{*}{-} & \multirow[t]{2}{*}{13} & \multirow[t]{2}{*}{75} & \multirow[t]{2}{*}{7} \\
\hline & & \multirow{2}{*}{\multicolumn{2}{|c|}{22}} & & & & \\
\hline \multirow{2}{*}{ 太平洋沿岸 I } & \multirow[t]{2}{*}{74} & & & \multirow[t]{2}{*}{1} & \multirow[t]{2}{*}{3} & \multirow[t]{2}{*}{70} & \multirow[t]{2}{*}{30} \\
\hline & & 65 & 35 & & & & \\
\hline 太平洋沿岸而 & 26 & \multicolumn{2}{|c|}{45} & - & 29 & 100 & 24 \\
\hline \multirow{2}{*}{ 太平洋沿岸IV } & \multirow[t]{2}{*}{-} & \multicolumn{2}{|c|}{33} & \multirow[t]{2}{*}{-} & \multirow[t]{2}{*}{67} & \multirow[t]{2}{*}{33} & \multirow[t]{2}{*}{1} \\
\hline & & - & 100 & & & & \\
\hline 相模湾·東京湾沿岸 & 29 & \multicolumn{2}{|c|}{$\frac{1}{54}$} & - & 17 & 59 & 5 \\
\hline
\end{tabular}



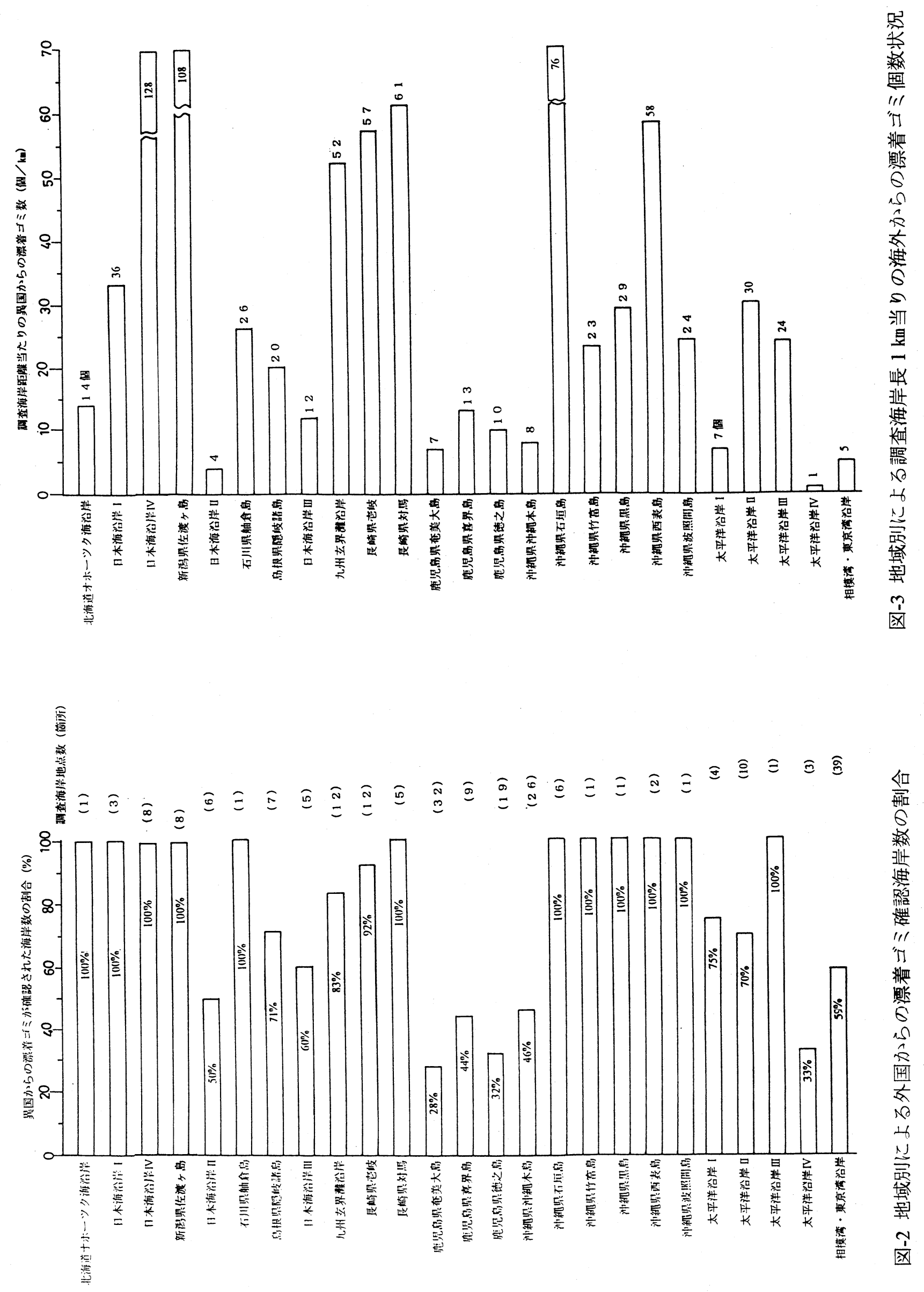
ゴミ個数が、20 個と 10 個で比較的少ないが、一部の海岸では外国からの漂着ゴミ個数が、かなり高い海岸 もあった。特に外国からの漂着ゴミ個数の高い調査海岸地域は、日本海沿岸 I とIV及び佐渡ヶ島の秋田・ 山形・新潟県の日本海沿岸、九州玄界灘沿岸と壱岐・対馬及び石垣島・西表島の東シ十海上の島々で、いず れも $1 \mathrm{~km}$ 当りの漂着ゴミ個数は 30 個以上となっている。取り分け多いのは、日本海沿岸IVと佐渡ヶ島で、 128 と 108 個に達している。日本沿岸IVでは、飛島の海岸に漂着したゴミが大部分を占めている。外国から の漂着ゴミ個数が $1 \mathrm{~km}$ 当たり 20 個以上確認される海岸域は、識別できない漂着ゴミを考慮すると、外国か らの漂着ゴミ污染問題がかなり深刻な状況にある。舳倉島、隠岐諸島、竹富島、黒島、波照間島の離島でも 20３0 個の漂着ゴミ個数を示している。上述したように、奄美大島、喜界島、徳之島、沖縄本島で 10 個/ $\mathrm{km}$ 前後の比較的少ない值を示しているのは、海洋上を漂流・浮遊しているゴミが、対馬海流と逆方向に南下 する傾向が低いことと、台湾方面から海流に乗って北上に運搬される漂流ゴミが南に位置している先島群島

(波照間島〜石垣島) に先に漂着する可能性が高いためと考えられる（後述する図-4 と 5 参照)。また太平 洋側に着目すると、太平洋沿岸 II とIIIではそれぞれ 30 と 24 個 $/ \mathrm{km}$ と、日本海沿岸や東シ十海上の島々に相 当する結果を示す海岸域もある。

そこで、地域別ごとに確認された外国からの漂着ゴミ個数に基づき、4 種類のタイプに区分し、その割 合を百分率で比較したのが図-4 である。この結果から、日本列島に漂着する外国からのゴミの状況には大 きな特徴があることが分かる。

(1) 日本海沿岸IVと北海道才ホーツク海沿岸の結果から、東北地方以北の日本海側の海岸域には、ロシ ア語系ゴミも漂着している可能性が高い。北海道オホーツク海沿岸の小清水町の海岸には、ロシア語系ゴミ が外国からのゴミ総数の $20 \%$ に達している。

(2) 沖縄本島より以北の調査海岸域（太平洋側を除く）では、ハングル語系の漂着ゴミが圧倒的に多く、 ゴミ総数の $60 \%$ 以上を占め、80\%以上の海岸域が大半を占めている。

(3) しかし沖縄本島より以南の先島群島（石垣島、竹富島、黒島、西表島、波照間島）では、中華語亲 ゴミが主体となり、外国からの漂着ゴミ総数の 60〜70\%前後に達している。逆にハングル語系ゴミは激減 し 10\%前後となり、15２0\%の英字系等（その他）のゴミより多少低い值を示している。

(4) まだ未調査ではあるが、太平洋側の若干の調査結果から、太平洋沿岸に漂着してくる外国ゴミの主 体は、2 種類に大別される可能性がある。千葉県銚子付近の海岸域を境として、それよりも北方の海岸域で は、日本海側を北上して漂流するハングル語系を主体としたゴミが、津軽海峡を通り太平洋側に出て、親潮 に乗って南下して漂着するもの。一方、銚子以南の海岸域では、中華系ゴミを主体に、黒潮に乗って北上し て漂着するもの。と思われる (今後、この推察について現地調査を予定している)。

上述した(1)、(2)、(3)、(4)項目の特徴的事項から推察すると、我が国に漂着する外国からのゴミは、主に、 ロシア語系ゴミの場合は東北より以北の日本海、オホーツク海の海域、ハングル語系のゴミの場合は奄美群 島より以北の東シ十海・日本海の海域、中華語系ゴミの場合には先島群島より以南の東シナ海や先島群島近 海の東シナ海域を漂流・浮遊し、我が国の領海内に移動し、日本列島の広域な範囲の海岸域に亘って漂着し ているものと考えられる。

さらに図-5 に示すように、中華系のゴミにも特徵が認められる。この結果は、中華語系ゴミが 10 個以 上確認された調査地域で台湾系と中国系（旧香港含む）に区分して比較したものである。石垣島より以南の 先島群島では、中華語系ゴミの総数の約 70\%以上は台湾系ゴミが占めていた。これに対して沖縄本島より 以北の海岸域では、多少ばらつきはあったが、台湾系ゴミが 20〜 40\%と減少し、逆に中国系ゴミが増加す る傾向がある。このようなことからも、中華語系ゴミの産出・発生海域は台湾系と中国系と異なると考えら れる。上述したように台湾系ゴミは先島群島より以南の東シナ海の海域、中国系ゴミは先島群島より以北の 東シナ海上の海域から主に漂流し、我が国に漂着して来るものと推察される。 

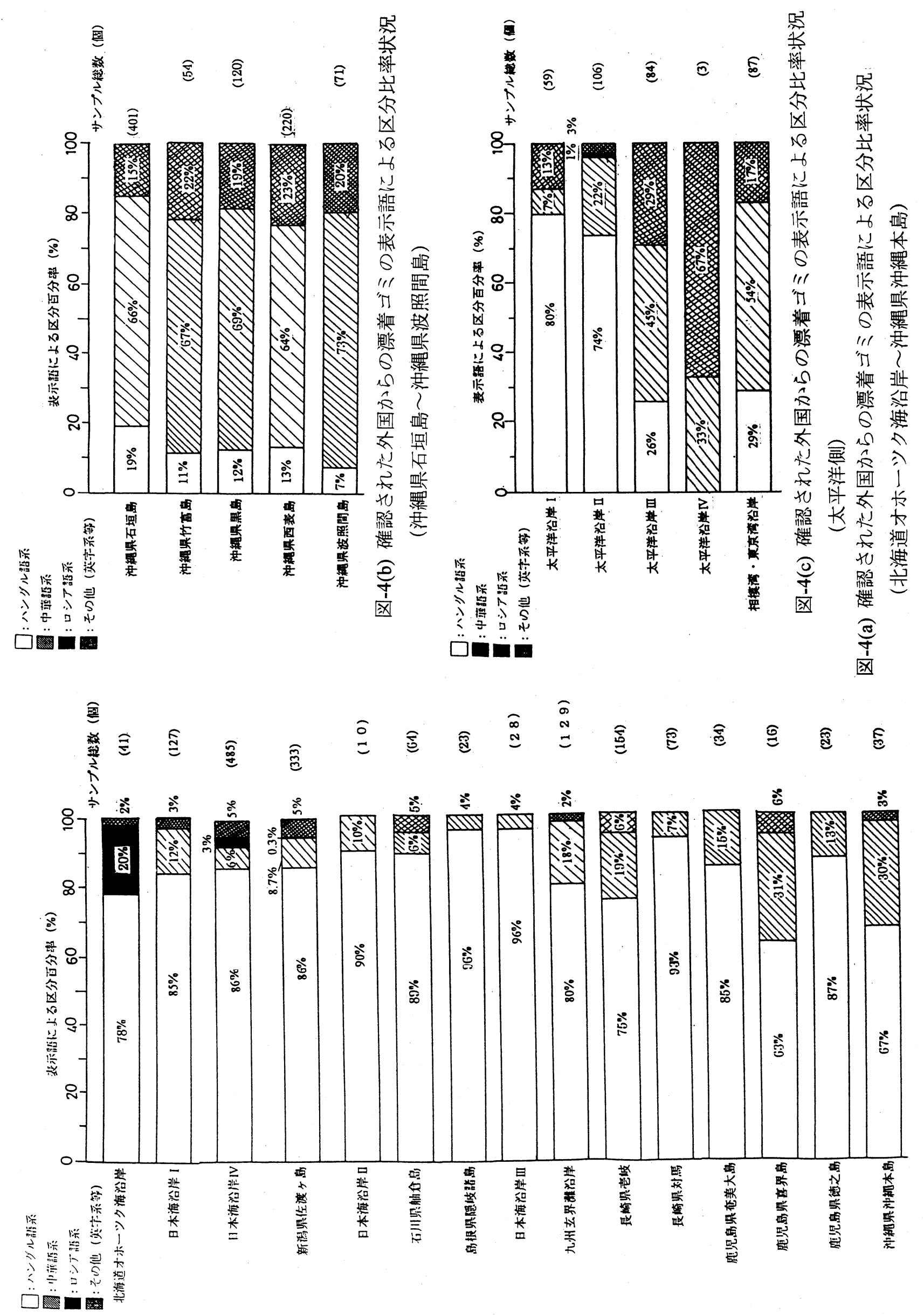


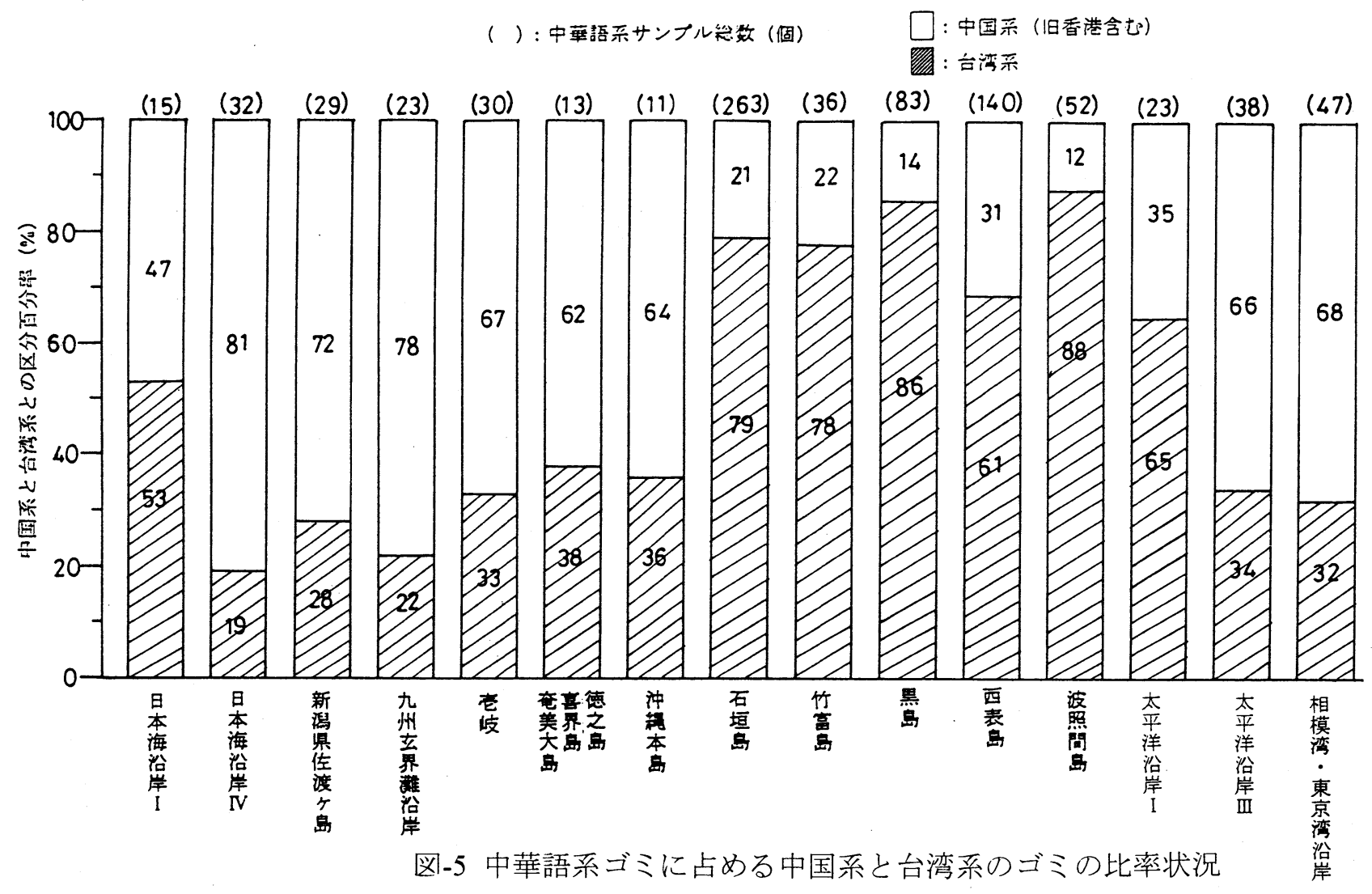

\section{5. 今後の課題と対策}

日本列島の海岸域が外国から漂着するゴミによるゴミ箱と化さないようにするためには、まずもって国 機関による早急な調査・対策が必要である。発生源に迫り対策を確立するためにも、

(1)詳細な漂着域の把握調査

(2)季節的変動を考慮した漂着ゴミの詳細な種類と量の調査

(3)発信器等を利用した漂着ルートの解明調査。

(4)ゴミ漂着による海岸污染と被害状況の実態調査。

が不可欠と思われる。また海洋越境する漂着ゴミU海岸污染問題は、大陸越境する大気污染（酸性雨など） 問題に匹敵するので、地球規模的問題ともとらえられる。近隣諸国とのゴミ問題についての話合いや対処方 法について積極的に協議していくことが是非とも必要である。なおここでは、外国からのゴミが我が国に漂 着してくる問題を取り上げた。しかし、我が国のゴミが自国の海岸線を污染していることも、当然、非常に 深刻な問題である。また、我が国のゴミが八ワイ諸島など他国に漂着するという話もよく耳にする。海岸域 の漂着ゴミ問題は、これらの問題も含めて調査・検討していくことが重要な課題と考えている。

\section{参考文献}

1) 山口晴幸ら(1996) : 日本列島砂浜海道巡礼一日本名浜百景・砂浜百選の提言一、土木学会誌 10 月号、pp.54 $\sim 57$.

2) 山口晴幸(1997)：ロシアタンカー流出重油日本海沿岸を襲う、土木学会誌 4 月号、pp.28～34.

3）山口晴幸(1998) : 外国から漂着するゴミによる海岸污染、土木学会誌 3 月号、pp.47 49.

4) 山口晴幸(1997) : 外国製ゴミ大量漂着、毎日新聞、平成 9 年 11 月 1 日発刊 (夕刊).

5) 山口晴幸(1998) : 漂着ゴミ大量に、日本経済新聞、平成 10 年 2 月 3 日発刊（夕刊）、他に 30 新聞社に掲 載. 